\title{
THE STIFLING OF THE HUMAN SPIRIT AS PORTRAYED BY THE PLAYWRIGHTS SAM SHEPARD AND. DAVID RABE
}

\author{
Prof. Dr. Gönül UÇ்LE \\ Assoc. Prof. Dr. Ayșegül YÜKSEL
}

Every now and then a nation feels the necessity of reviewing its past in order to come to terms with its present, and to reach a new definition of itself. In the last quarter of the 20th century, the U.S.A., like many other nations, seems to be faced with this necessity. Throughout the history of the U.S.A., American society has lived through a long process of constant progress which has made America one of the most developed countries as well as a world power. Along the way, American society has created its own mythology and at the same time exhausted the very myths it has created. It has been a long time since the Western frontier was reached; the farmer who ventured towards the west to capture and "tame" the "wilderness" is no more "the social ideal". The prairies are no longer trodden by the "lonely rider", the tough, hard-headed cowboy, who had built the myth of individual heroism. America is no more the virgin land to be discovered, explored, and exploited by pioners.

Now technology has taken control; it has eliminated nature in the process of urbanization and industrialization. While bringing the individual prosperity, it has limited the individual's aspirations, by leading him to conformity with the rules of the "American way of life", which means securing material possessions and running the race "to the top" in a process of endless competition. This standardization of "man" and "the family" in conformity" with the ideal of progress, has resulted in the individual's isolation and inarticulation. On the other hand, the "nation that took pride in its heritage of freedom" also faced the dilemma that "while America was defending the cause of freedom throughout the world, she was denying it to 
twenty million (black) citizens at home"1. The heroic venture of the nice and square American soldier, the savior of the nations under. German occupation, lost its romantic flavor especially after the Vietnam War and came to mean pointless intrusion. What holds the national imagination now is the venture into space, the most recent myth of American heroism. Yet, the tragic accident which followed the launching of the space shuttle "Challenger" last year has come as too early a blow.

The once-cherished image of "All-American" middle class has been gradually fading; there are too many broken homes. Crime and violence have become a threat in big cities. The sexual revolution has also had its disappointing consequences. There is too much drug and TV addiction. In short, too many things seern to have got out of proportion.

Both as a world power operating on delicate balances and as a vastly populated country which can no longer hold the imagination of its people by "dreams" common to all, the U.S.A. is now to reach a new sense of proportion through which new values can replace the old ones...

Serious American drama has more often than not undertaken the task of attacking the "American dream" in its various aspects. This also holds true for the new theatre movement since the 60 's, which, experimental in form, aimed at startling and shocking the audiences so as to dislocate the sense of well-being and the complacency of the American society. In the same years that experimental theatre began to make itself known with the revolt against the commercial theatre identified with Broadway, the terms off-Broadway and especially off-off-Broadway-created by the efforts of people who were in need of new frontiers-became the pass-words of the anti-establishment.

Many critics share the opinion that since Edwards Albee, Sam Shepard and David Rabe have been the most significant playwrights, who, in the 70's and 80's have produced a considerable body of work for the new movement in American theatre. Both playwrights aim at dramatising man's experience in a society which has lost many of its myths-the kind of experience that ends up by stifling the human spirit...

1 James A. Coloiaco, "The American Dream Unfulfilled", Phylon, Vol. XLV No. 1,1904, p. 16 . 


\section{SAM SHEPARD}

Among the playwrights in the new theatre movement who aimed at startling artd shocking the audiences Sam Shepard seems to have an outstanding position. Hailed as a "shaman" and a prophet by some circles, he is decidedly one of the most prolific playwrights that the U.S.A. has produced in the last two decades. He has proved to audiences that he is serious about playwriting and highly concerned about some vital issues of American life.

However, the handling of similar anxieties and themes is done in a very unique manner characteristic to Shepard and the cult and/or generation he is identified with. For like most artists of the 60's, he turned to folk art, the frontier myth, rock-and-roll and his own interpretations of a world of abrupt transformations. Jack Kroll states that Shepard has to be accepted as he is in order to be given due appreciation:

At 35 Sam Shepard is prolific, incorrigible, restless, vital; the bucking bronco of the American theater. Since his first play Cowboys in 1964, he has almost certainly written and produced more plays than any other American playwright-none of them on Broadway. In some crazy way Shepard seems almost to have become the alter native American theater. I'm not the only reviewer to have croaked out lemantations over Shepard's "failure to develop". But I give up. He is beyond such niggling and caviling. You take him as he is-intense with poetry and theatricality, a dowsing rod for the dark pools of myth in American life-or you don't take him. The theater being what it is, you'd better take him. ${ }^{2}$

Shepard is a typical product of the forties and fifties and like most of the artists born in the forties he brought his inheritence with him when he made his debut into the theatre world. He went through the rebelliousness of the young people personified in James Dean's image in his Rebel Without a Cause, recklessly driving fast cars, taking drugs to get stimulated, living in a close embrace with danger and death. Patti Smith, Shepard's one-time girl friend in a poem-like narration 9 Random rears comments on his wild and reckless life:

2 Jack Kroll, "Bucking Bronco", Newsweek, Oct. 30, 1978. 
.... when he was grown had húbcaps in his own on a

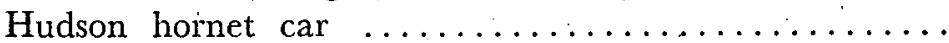
he plunged off a cliff the people all gathered and pointed to him they said there goes a bad boy ${ }^{*} . . . \ldots \ldots \ldots . . . .$. $\mathrm{He}$ was bad

a drunken kid

He yodelled like a cowboy...

he was a renegade with nasty habits

... and pleased with his Cowboy aria etched in sticky chocolate, he headed East.

Theatre in his pocket and a salamander in his shee he thumbed it toward the great white way ${ }^{3}$.

His lucky break came in 1964 when his first plays Cowboys and Rock Garden were produced at Theatre Genesis, followed by Chicago and many others. His later collaboration and close contact with the Open Theatre and Joe Chaikin allowed and opened the way for further experimentation. $\mathrm{He}$ is a highly visual writer who also makes ample use of music in most of plays. His works reflect decay, death, loss of identity and naturally they have the "shock" element of the other experimentalists but the most interesting aspect of his work probably remains in his reaction to the destruction of nature, the loss of innocence and purity that go with this wanton destruction of the mother earth. This problem which bothers him comes up frequently in his plays as contrasted to his disgust of the steel jungles of big mechanized cities and their equally mechanized, robot-like inhabitants.

Chicago is probably the best example of his concern with mechanization. The main character', sitting in a bathtub throughout the play, voices his disgust with the civilized world and people. His sitting in the bathtub is his way of protesting, his way of escape from the outside world he criticizes so bitterly. Through Stu, Shepard's cynicism in the good intentions of modern man comes out very clearly for he sees them as the willing agents in this destruction process that has become so hateful for him. He grieves for the loss of beauty, the loss

3 Patti Smith, "Sam Shepard, 9 Random Years", in Sam Shepard's Angel City and Other Plays, New York, Urizen, 1980, pp. 241-43. 
of life and natural growth of nature. The Curse of the Starving Class, another important play includes the motif of a disintegrating family in a rural area in contrast to the urban sophistication of Chicago. The mood of the Curse of the Starving Class is that of a fading American dreama disjointed family; lack of loyalty or attachment of any sort, defiling of nature by men who are crazed with dreams of success and wealth. In a review of the play, Douglas Watt gives a similar commentary: ... It is a bitter farce, a desolate tragicomedy variation of the writer's favorite theme, the stifling of the American spirit by unseen, unknown forces gobbling up the land and the soul of its people in the name of progress ${ }^{4}$.

As mentioned before, Shepard is dealing here with an absurdly disjointed family: scatterbrained mother-pretending that she's keeping house but oblivious to her children's needs; drunken, ragged and mostly absent father; bright but corrupted 13 -year old daughter, and emo- tionally numb, sacrifical lamb of a son. Their home -a ranch-is about to be lost, for the father, deeply in debt, has signed away, the property. It is a family that can describe itself in the play: "We are not rich. We are not poor. We are something in between.". Yet everywhere Shepard sees violence, alienation, betrayal and hopelessness and filth. The garbage of the cities represented by the garbage of ice-boxes, people failing to communicate-husband to wife, parents to children.' Indeed, in total, starvation in the land of plenty, or at least, in the land of sufficient. Heavily layered with symbolism, the play also offers touches of realism with a genuine lamb brought onto the stage or one of the characters actually appearing to urinate during a scene. Shepard's. The Curse of the Starving Class stands as a strong and difficult play with its complexity and dense structure but it has prepared the way for his next big work which is resembled to a Pinter .play: The Buried Child, his second family play in a row. Both plays deal with families driven to an extreme of eccentricity hardly distinguishable from madness by the pent-up pressures of violence and guilt. Shepard rivals Pinter in his sense of the family as a spilt atom whose particles have been knocked into cockeyed orbits. In Buried Child, the particles are the grandparents Dogde and Hallie, wrenched apart by a festering murder; their sons, the one-legged Brodley and the spooky farmer Tilden and their longabsent grandson Vince. The

4 Douglas Watt, "In the end, emptiness", Daily News, March 3, 1978.

5 Ibid. 
play deals with the homecoming of Vince; who has been away for six years, with his girl friend Shelley, to the parental farm which had been flourishing before he left. His dream is to settle down in this bucolic environment, get to know his family and his roots. However, what he finds is a house of the dying, full of grotesque clinging to guilty secrets, the most shocking being the grandfather's murder of an unwanted child and burying it on the farm. The whole thing is a far cry from what the girl friend has been told to expect. Instead of the cosy atmosphere and loving attention, she gets assaulted, insulted and set to do menial jobs, while the son fares even worse, for his relatives do not acknowledge him at all. His dreams of coming home and finding his roots have been poisoned by the America that Shepard portrays as a destroyer of life. This play, perhaps more than the rest, clarifies Shepard's debt to Pinter and Edward Bond, says Clive Barnes:

... it clarifies Shepard's undoubted debt, acknowledged or not, conscious or sublimal, to the British playwrights, Harold Pinter and Edward Bond. The Pinter feeling here in this homecoming is very strong... The situation, the air of unspoken menace, ... the mystery of incidents, it is all, as they say, Pinteresque. From Bond, Shepard seems to have adopted his feel for grotesque violence... Yet this aspect is only part of Shepard... The melodic construction derives from an earlier American tradition. 6

What is more, the theme of the play is also American in that Shepard's major dramatic concern with the past is highly reminiscent of O'Neill's preoccupation with the past. According to O'Neill nobody could escape his past; none of his heroes or heroines achieved this. The Man nons, The Tyrones and The Melodies suffered because their past always caught up with them and the same is true for the members of Vince's family in Buried Child. Toward the end of the play someone asks, "The Past- what do you know about the past?" It could almost stand as a symbolic statement of Shepard's major dramatic concern. In a more recent play, Fool for Love, the cycle seems to be completed because the theme of incest tied up with the writer's obsession of the past brings to mind the doomed family of the Mannons in O'Neill's Mourning Becomes Electra. Again like O'Neill, Shepard

6 Clive Barnes, "Menace, mystery in Shepard's Buried Child, New York Post, December $6 ; 1978$. 
seems to be haunted by the idea of death in nearly all his plays, displaying the same dark, pessimistic outlook on life. In another work, done in collaboration with Joseph Chaikin, who took up acting after his group disbanded, the theme is once more death and dying. This focusing on death in Tongues came partly from their interest in expressing the extreme conditions, partly from an idea they had, to structure the piece as a fantasy of the past life of a dying man and partly because Chaikin was literaly going through heart failure. ${ }^{7}$

Tongues circles back again to death. It is about a man who hiles "in the middle of a people", is honoured, dishonoured, married, becomes old and then one night dreams that a voice is telling him that he is dead. The starkness of the piece is relieved by music and Shepard's music for Tongues is a concert of varied percussion on traditional and invented instruments-bongos, drums, bells, kitchen: utensils. ${ }^{8}$

Whatever may be said about Shepard, the fact remains that he is decidedly one of the most prolific and promising of young playwrights who will leave their stamps on theatre and art for the future generations. He has the makings of a poet and what is more he is authentic and sincere in his outbursts and rebellion against the "unseen forces" that are devouring his country and its people. Jack Gelber in the introduction to Angel City writes about Shepard's theatrical vision which manifests itself in the form of "trips", quests and adventures:

... it takes a glance to recognize that (the Plays) are trips... Many of the characters are on drugs, some are high on music... These visionary beings are in search of gold, fame and love as indeed the principals... And all of this action takes place in play after play on a bare or nearly bare stage accompanied by spell-binding music and trance-inducing monologues.

Gelber then gives the reader his definition of Shepard as a shaman: Anthropologists define the shaman as an expert in a primitive society who, in a trance state induced by drugs or music or other techniques, directly confronts the supernatural for the purposes of cures, clairvoyange, the finding of lost objects and the foretelling of the future. Sam She-

7 Eileen Blumenthal, "Chaikin and Shepard Speak in Tongues", The Viliage Voice, November 26, 1979, p. 103.

8 Blumenthal, p. 109. 
pard, ... my hypothesis runs, is a shaman- a New World shaman... Sam is as American as peyote," magic mushrooms, Rock-and -Roll and medicine bundles.... American Indian shamans regularly use drugs to induce trancelike stances which carry them on their trips to the spirit world. The primitivist in Shepard parallels this experience with certain characters in his plays... The emphasis is on the trip, the personal visions, the shamanistic goal fulfilled along the way-in short the metaphysical. It is not important for Shepard to examine the social, economic or political implications of drug taking... His design is to promote a theatrical condition between the actor and the audience similar to an ecstatic state which will allow him to - fulfill his shaman's role within the play and between the actor and the audience. 9

Shepard, writing of himself and of his style, mentions his efforts to find new forms that would take the writer to another world:

What I'm trying to get at here is that the real quest of a writer is to penetrate into another world. A world behind the form.... it's generally accepted in the scholarly world that a playwright deals with "ideas". That idea in itself has been inherited by us as though it were originally written in granite.... The problem for me... is that its adherents are almost always referring to ideas which speak only to the mind and leave out completely the body, the emotions.... Myth speaks to everything at once, especially the emotions. By myth I mean a sense of mystery and not necessarily a traditional formula. A-character for me is a composite of different mysteries. He is an unknown quantity. If he wasn't; it would be coloring in the numbered spaces. ${ }^{10}$

Nearly all his plays" are explorations of the unknown and of the mysterious in accordance with his quest "to penetrate into another world" and regardless ' of their complex, violent, pessimistic overtunes, they are visible examples of his achievement as a corrocive commentator of American life. A final trait of Shepard is that he is really concerned

9 Quoted from Jack Gelber's, "Sam Shepard: The Playwright as Shaman" in Angel City; pp. 2-3.

10 Sam Shepard, "Visualization, Language and the Inner Library", Drama Review, Volume 21, Number 4, December 1977, p. 55. 
with serious issues and tries to bring some sort of solution to such; an inclination which is most obvious in his Cowboy Mouth where he hopes to restore the long-lost values by combining the old and the new, forming a new cultural myth. Cavale's wish for a saviour that is a mixture of "a street saint... a saviour with a cowboy mouth"11 indicates on Shepard's part as well a nostalgic wish for a restoration of all that has been lost. As Bonnie Marranca points out, ${ }^{12}$ Sam Shepard, at his best, illuminates the social and cultural politics of America even as he reveals his own highly emotional response to life. And, at his worst, he mirrors. American self-indulgence and immaturity. Above all, Shepard's ability to translate his vision into his own wonderful dreamscapes, wherever they may take him, makes him a dramatist who continues to surprise and elate us.

\section{DAVID RABE}

David Rabe is the more educated of the two playwrights. He holds an M.A. degree in theatre and has taught in the graduate theatre department at Villanova. Unlike Shepard, Rabe is the kind of playwright who loves to write elaborate comments on his own plays. Unlike Shepard, he is not a very prolific playwright. He produced only six plays between 1971 and 1984.

Rabe served in the Army from 1965 to 1967 and he spent the final eleven months in Vietnam. That is one of the reasons why the Vietnam War has become a major theme in his drama. Yet it is quite clear that Rabe, is not merely occupied with writing anti-war plays. His main intention as a playwright is to dramatize the disturbing experiences which made up an important part of the-American scene in the 60's and the 70's. So, in Rabean drama the Vietnam experience serves more as a means to shape dramatic situations than as an end in itself. Through the striking dramatic situations based on the Vietnam experience, Rabe explores the experiences which lead to the stifling of the human spirit in a complex society which has started questioning its values, its myths and its dreams.

11 Shepard, Angel City, p. 208.

12 Bonnie Marranca-Gautam Dasgupta (Vol. 1), American Playwrights: A Critical Survey, New York, Drama Book Specialists (Publishers), 1981, p. 111. 
"Disappointment" and "rejection" lie at the core of Rabean drama. Some characters are victimized by the false ideals offered to them by the society. Some find that the myths with which they identify themselves have let them down. Some others, on the other hand, face a meaningless existence due to the absence of myths or values on, which they can base their efforts towards well-being. Self-deception, isolation, lack of communication, inarticulation, racism, sex, violence and crime are recurrent themes in Rabe's work.

Rabe has won recognition as a leading dramatist by his so-called "Vietnam Trilogy", which includes his first play; The Basic Training of Pavlo Hummel (produced in 1971), his first "best" play, Sticks and Bones (produced in 1971) and a later work, Streamers, his second "best" play (produced in 1976).

In The Basic "Training of Pavlo Hummel, the "dream" that lets you down is the once attractive image of the American" soldier, the independent, self-sufficient, tough guy "proud of his uniform, his profanity and sexuality" 13 The hero is Pavlo, a naive and confufused lad raised by indifferent parents into an insignificant existence in New York: Due to lack of inner resources to help develop his own image of manhood, Pavlo adopts the image of the All-American Army Volunteer in Vietnam. As the only enthusiastic participant in the process of basic training, he is soon transformed into a death-machine. Pavlo's efforts to become a military hero, the symbol of "physical courage" and "sexual prowes": 14 which he believes will win him recognition in the society which otherwise ignores him, are contrasted by the reluctance of his fellow recruits who fear and hate fighting. It turns out that "the war itself is an emblem of cowardice and despair" 15 which presents an equally unpleasant and disturbing picture of the American and the Vietnamese. Yet, having fully experienced the horror and pain brought about by the war, Pavlo still fails to see the reality behind his false-ideal. Ironically, he is killed by a fellow soldier in a quarrel over a prostitute. Still unaware of his self-deception, the dying Pavlo is only conscious of the

13 Catharine Hughes, American Playwrights 1945--75, London, Pitman Publishing, 1976, p. 132.

14 Janet S.. Hertzbach, "The Plays of David Rabe: A World of Streamers" Essays on Contemporary American Drama, eds. Hedwig Bock and Albert. Wertheim, U.S.A.: Max Heuber Verlag, p. 174.

15 Ibid., p. 174. 
fact that his experience in the Army has been disappointing: "It all shit!" An expression of his total confusion and inarticulateness...

In Sticks and Bones, Rabe's target is the myth of the All-American middle-class family. The characters are taken from the popular radio and television comedy, "The Adventures of Ozzie and Harriet", based on the daily experiences of the Nelson family, consisting of Ozzie, the father, Harriet, the mother, and their two sons Dave and Rick. C.W.E. Bigsby describes these series as "a sentimental celębration of American values", which "excluded any evidence of anxiety and pain"16. In Sticks and Bones Rabe experiments with the same family by inflicting pain and anxiety upon their life. He sends David, one of the sons, to Vietnam...

The characters in Rabe's play have managed to get over the "disappointments of their existence" by adopting their respective roles within the image of the nice American middle-class family and "have settled for a bland contentment which they take for happiness" 17 Then David returns from war, physically blinded and mentally disturbed by an overwhelming sense of guilt owing to his experience in. Vietnam. After the first shock of the news of his blindness, the family tries to get him oriented to his "good old life" as if nothing has changed. They ignore his blindness and his experience in Vietnam, because "their own myths (...) cannot acknowledge such disruptions." 18 But David has completely changed. He is now a stranger in his home and his country. Unlike Pavlo, he has gained insight into the realities behind the superficial values of the "All-American" family. He hates Harriet whose role as mother seems to be limited to feeding everybody all the time and keeping things clean. He hates Ozzie for having lost his aspirations and independence, for avoiding realities by escaping into the world of false images provided by the TV, for the pleasure he used to get out of teaching his sons rough gamies. He despises his brother Ricky, a self-satisfied boy who plays the guitar, takes photographs with his polaroid camera, goes on dates with girls, and feeds greedily on fudge and soda, avoiding all kinds of trouble by popping in and out of the house, signifying his presence or absence by his endless utterances, "Hi, Mom", "Hi, Dad", "Bye, Mom", "Bye Dad!"

16 C.W.E. Bigsgby. A Critical Introduction to Tiventieth Century American Drama, Volume

3, Beyond Broadway, London, Cambridge University Press, 1985, p. 326.

17 Ibid., p. 326.

18 Ibid., p. 326. 
Most of all, he hates the fact that the members of the family never attempt real communication with each other. David's rejection of the ways of his family and his preoccupation with Zung, the native girl he loved and left in Vietnam (and a symbol of his sense of guilt associated with the Vietnam experience) makes him an intruder upon the sense of well being of the family. As Bigsby notes, "their attempts" to accommodate him (David) to their banality and to refuse the implications of his experience become an image of a denial of reality which transcends Vietnam and of which Vietnam is merely an example"19 Instead of trying to understand David's feelings about Zung, who is the "image of corruption of which he accuses himself and his country", 20 they only feel horrified by the fact that their son has had a serious affair with a "yellow whore". Racism is one of their indispensible attitudes; for "racism answers the need to feel superior to some group" 21

The family makes a choice. They must get rid of David, who threatens the myths on which their sense of well being has been built. They encourage David to commit suicide. In a shocking scene, David is ceremonially sacrificed so that the myth of the "happy. American family" can go on... Perhaps Rabe is making the point here that "domestic American violence is, after all, as terrible as the literal violence in "Vietnam." 22

In his next play, The Orphan (produced in 1973) which proved to be a failing attempt to remodel Aeschylus' Oresteia for the sake of contemporary comment on the American scene, Rabe once more drew the symbolic parallels. between violence at home and in Vietnam. The Orphan also shows that in Rabe's work Vietnam has come to be the symbol of irrationality and violence anywhere at any time.

In the Boom Boom Room (also produced in 1973) is another play that failed. It is Rabe's first play which is not associated with the Vietnam experience. Yet, it involves the very themes of sex, violence, racism, self-deception, attachment to false-ideals, isolation, and inarticulation that the Vietnam plays deal with. This time the protagonist is a woman. Chrissy, a naive and insignificant go-go dancer who feels that she is a potential Marilyn Monroe, cherishes the dream that she

\footnotetext{
19 Ibid., p. 326.

20 Ibid., p. 326.

- 21 Ibid., p. 326.

22 Ibid., 326.
} 
will one day end up in New York as a big star. Instead, she is exploited, victimized and despised by everybody along the way. She is brutalized by men and becomes the object of every kind of sexual attitude. She actually ends up in New York: but as an ordinary "topless" dancer, a mere sex object who has to wear a hood to cover her face due to the black-eye a boyfriend has given her. The irony is clear. Like Pavlo, all her efforts to achieve some kind of identity have been wasted. Unlike Pavlo, however, Chrissy is aware of the fact that her "myth" has let her down.

Streamers (produced in 19.76) is the third play in the Vietnam trilogy, and Rabe's second "best" play. Streamersfocuses on the occupants of the Army barracks, who will soon be dispatched to Vietnam. Circumstance has forced three men from different social backgrounds to share a common daily life in the barracks; Richie, a white homosexual from a broken family; Billy, another white from a conventional middle-class family and a former high-school sports star; and Roger, the black, who has moved away from the ghetto and adopted the values of conventional society.

The life in the barracks is dominated by an over -whelming sense of fear- the fear of being sent to a meaningless war in which there is no glory, but only suffering and destruction. In the meantime, life in the barracks offers no consolation, for the three young men find that there is no comradeship or communication between them. Richie makes advances to Billy,-who, greatly disturbed, chooses to ignore the fact that Richie is a homosexual. Billy and Roger try to evade stress and panic by sticking to their sense of deceny and respectibility which manifests itself in their constant waxing and mopping of the floor and their attachment to sports.

Yet, their efforts to maintain some "homelike" order in the life of the barracks are to be wasted: their assumed peace and quiet is disturbed first by two pathetic sergeants who have actually experienced war, and have retreated into an unreal world of heavy drinking and childish games. Then comes Carlyle, the bad black gay, who, resenting his ghetto unbringing, has declared war against all the values of conventional society. Rabe draws all the possible contrasts between the characters. While Billy sticks to the myth of the "good male" from a "jolly" good family, Richie defies Billy's myth by his attempts at an "improper" sexual relationship with him. (After all, Billy has has also had his days of indulgence in perverse sex!). The two black 
men, bound together by the color of their skin, are also torn in conflicting attitudes. Roger understands Carlyle's outbursts of hatred and fear; Yet, he is no partner to Carlyle in his abuse of conventional society. The white and educated Billy is set against the black and uneducated Carlyle. In the end, the "two outcasts", Richie and Carlyle "connect in a sexual pact born at least as much out of loneliness and despair as from physical craving"'23. Billy defends his "myth" by standing up against their attempt at sex in the barracks and ends up by being stabbed by Carlyle. What he has feared has come too soon, even before his going to Vietnam. The drunken sergeant who happens to drop by becomes Carlyle's next victim. Two stupid murders signifying the fact that irrationality and violence in the American scene can no longer be controlled by the values of conventional society: In Rabe's opinion the Vietnam War is simply a projection of this fact. Hertzbach notes that "Rabe uses the war in Vietnam as a generalized backdrop for his reflections upon the inevitable, natural violence of American life" 24 . Streamers which means parachutes that fail to opent serves as a metaphor in the play. Billy, Richie, Roger and Carlyle and the others, who represent a microcosm of American society, all face destruction, for the society can no longer provide them with "parachutes" that guarantee their safety and wellbeing.

Hurly Burly (produced in 1984) has followed eight years after Streamers. Cited as Rabe's third best play, Hurly Burly shows that Rabe has abandoned the theme of Vietnam. The play takes place in a house on the Hollywood Hills, shared by Eddie and Mickey, good friends and partners in show business. Eddie is a drug and TV addict, who talks to the images appearing on the TV screen and suffers from long emotional lapses. Mickey, on the other hand, is more rational and seems to have complete control over his life. The two men have been divorced and have kids who live with their mothers. Artie, an older man in show business, and Phil, "a muscular anxious man", who is waiting for his "chance" as an actor in a "cop show" are their good friends and frequent visitors. The wives or the kids never show up; Donna, a tramp of fifteen is kept in the house as a sex object. There is aso Varlene, a professional woman who cannot decide between Eddie and Mickey, and, who concentrătes more on her work than on the two gentlemen.

23 Hetzbach, p. 178.

24 Ibid., p. 184. 
Within this dramatic framework, Rabe explorcs the confused role of the "male" in recent Amcrican society. On the one hand, "the codes of childhood" which have imposed on the male "determination, hardness, and dominance" are still effective. On the other hand, the Women's Liberation Movement is now claiming "rights" for which women "lacked desire" in the past ${ }^{25}$. And, faced with these contradictory commands which both come from women, the male is going through an identity crisis.

Mickey, Eddie, and Phil, three males from broken homes represent the three different attitudes adopted by the American male to face his identity crisis. Mickey is the one who never yearns about his broken home and talks about going back to his wife and children. Eddie is the one who sustains his unidentified position "with a wide variety of drugs". Phil is the most vulnerable of them all; he has "attempted to change", but has inevitably failed. His scnse of failure has led him to brutality. Yet, he cannot stand a life without a family. In short, Mickey has retreated into self-defense by ignoring the crisis; Eddie can only bear it with the help of drugs; Phil is crushed under the crisis and ends up by committing suicide. Mickey tries to avoid identifying with Phil by remaining cynical about everything he does; Eddie, on the other hand, takes Phil's problems to heart and unconsciously identifies with him. In short, they all represent the same male: the desperate parachutist whose "parachute" has turned into a "streamer". In this dismal world which shows that the "myth" of the "happy American family" has been blown off, women make their existence more effective even when they are simply used as sex objects.

But that is not all. Phil's failure in marriage is coupled off by his failure to rise in the show business. (Artie's hopes and dreams of "big contracts" make Phil's failure a more general one). After all, Phil is nothing but a big, muscular reality who can only be set in the background of a "fake" show to make it look real. Eddie, the only character in the play who is sensitive to all that is happening in the world, magnifies the "crisis" so as to give a whole picture of the American scene. It is not only "manhood" over which man has lost control, but also everything concerning "mankind". The neutron bomb annihilates people and "saves THINGS. It loves things. (...) Technology has fo- 
und a way to save his own ass" 26 Eddie is also shocked by an astraunot's statement that what impressed him most "up there" was "HIS ABILITY TO GET THERE"27 "Even the heavens have been emptied out and we no longer know into whose eyes we stare when we look for providence". 28

Eddie makes his passionate speeches concerning mankind either to Donna, who does not understand or care about a word of what he says, or to Johnny Carson, doing his show on the TV. Nobody hears Eddie. Nobody cares to listen to him. His articulateness deepens his isolation... How far can the human spirit be stifled?

David Rabe has been a swiftly developing playwright. He nó - longer needs the surrealistic images which haunt his earlier plays. His treatment of dramatic situations has become more straightforward. His dialogues are more challenging and his sense of humour has deepened. It is pleasing to observe that he has not exhausted his subjectmatter for drama.

Shepard and Rabe are two of the "new voices" who present the controversial aspects of modern American society. In a rapidly changing society such as the American society, there naturally have to be new voices and new trends along with what Robert Brustein calls "fads" and "cults". The "new theatre movement". in the U.S.A. has undertaken the mission of provoking the masses into an awareness of themselves and of the world by giving the audiences a "disturbing experience" in the theatre. Shepard and Rabe, among many others, have helped to shape this multi-dimensional and colorful period of recent American theatre.

26 Ibid., p. 117.

27 Ibid., p. 159.

28 Ibid., p. 117. 